\title{
Comparative Analysis of Viral Particles Using Different Electron Microscopy Methodologies
}

\author{
P. Soonsawad, ${ }^{*}$ S. Ma, ${ }^{*}$ D.G. Morgan, ${ }^{*}$ K. Hultenby, ${ }^{* *}$ L. Haag, ** S.-R. Wu, ${ }^{* * K}$ Forsell, ** \\ H. Garoff, $* *$ C-E. Hsieh, $* * *$ M. Marko, $* * *$ R.H. Cheng *,**
}

\begin{abstract}
*Section of Molecular and Cellular Biology University of California at Davis MCB Briggs Hall Room035 Davis CA 95616

** Department of Biosciences and Nutrition at Novum, Karolinska Institutet, S 14157, Huddinge, Sweden

***Resource for Visualization of Biological Complexity, Wadsworth Center, Empire State Plaza, Albany, NY 12201-0509
\end{abstract}

\begin{abstract}
Semliki Forest Virus (SFV) can enter a cell by fusing with the host membrane. To obtain detailed insight of the enveloped viruses, it is necessary to follow the progression in a sensitive and continuous fashion. In this study, the process of budding SFV was analyzed by combining techniques of electron tomography and high pressure frozen (HPF)/freeze-substitution (FS). The tomograms were examined by comparing them to a three dimensional (3D) reconstruction of purified SFV obtained from single particle reconstruction techniques and the size variation of budding SFV particles was examined. ${ }^{2,3}$ Here we report a comparison between six experimental parameters in samples imaged for tomography: osmium fixation condition (Fig. 1), section thickness, post-staining, usage of support film, single vs. double tilt and specimen temperature during data collection. The resulting measurements were compared with average measurements of frozenhydrated purified specimens. We found that the structure of the virus particles reconstructed tomographically correlated well with the electron density determined from frozen-hydrated samples. The data showed that different experimental methods can be used to observe specific details (membrane vs. neucleocapsid). Our experiment showed that electron tomography (ET) is a reliable method for 3D modeling. The data also revealed biologically important information such as the insertion of the viral protein into the target membrane. By using ET for reconstruction together with HPF \& FS for sample preparation, the measurement of whole viral particles showed the consistency of virus dimension with a systemic reduction of $15 \%$ in diameter, to that of the isolated single particle reconstruction with cryomicoscopy (Fig. 2).
\end{abstract}

\section{References}

1. J. Sedzik et a;. Res. Dev. Virol., 3 (2001) 310

2. M. Marko et al., Proc. Microscopy\&Microanalysis,(2000) 310

3. R.H. Cheng et al., Cell,80 (1995) 621

4. $\quad$ K Forsell et al., EMBO J., 19 (2000) 5018 

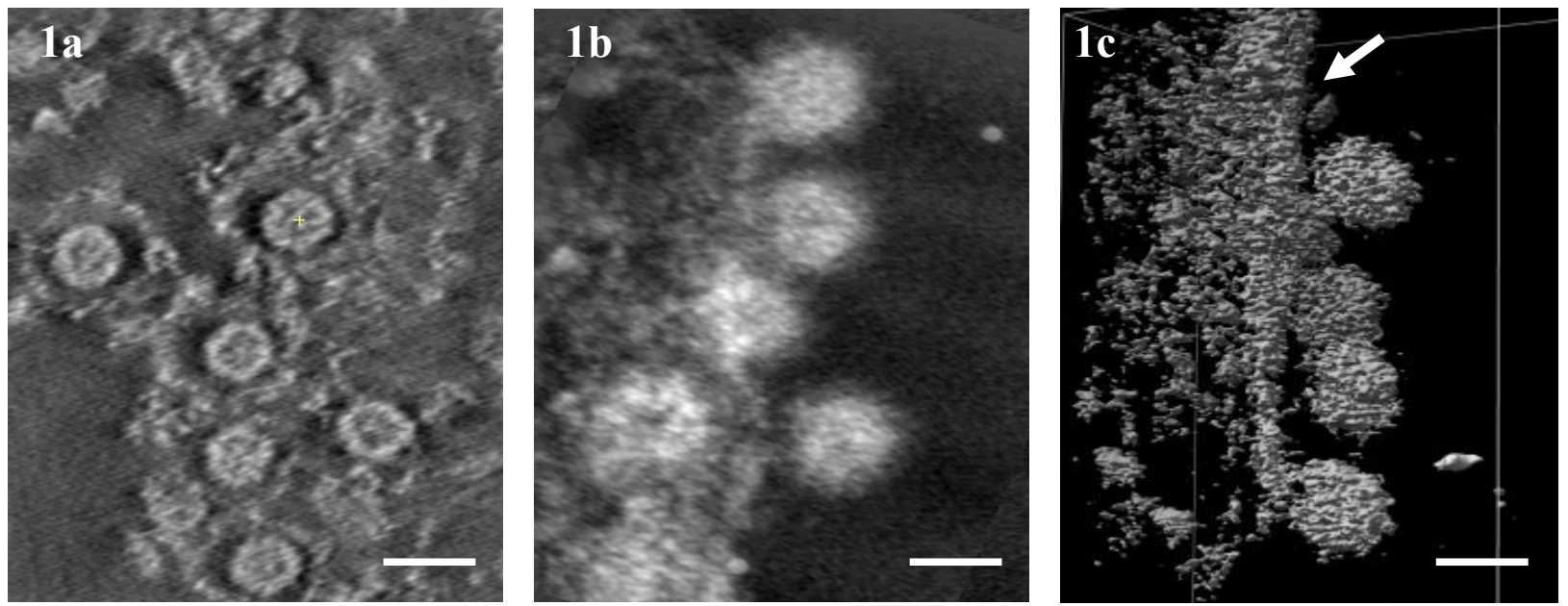

FIG . 1 The projection of the viral particles attached the membrane without osmium fixation (1a) and with Osmium fixation (1b). Surface rendering of (b) showed clear boundary of cell membrane (1c) (arrow). Osmium atom is extremely electron dense. With a double bond reaction to unsaturated lipid, the stain imparts a dense profile in the lipid region. $($ bar $=65 \mathrm{~nm})$
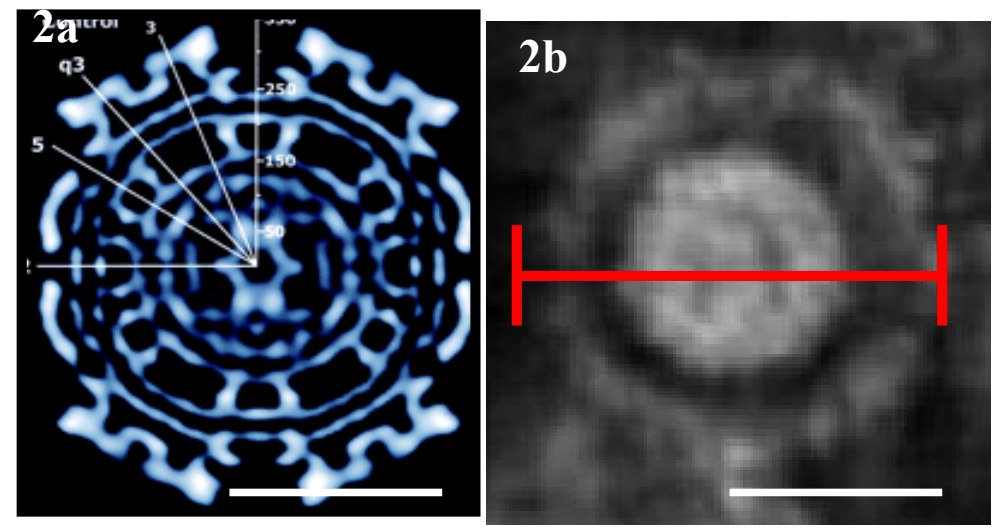

FIG.2 Two dimensional projection of SFV. The model show SFV through the central section. These measurements were made using single particle reconstruction (2a) and electron tomography (2b). (bar $=35 \mathrm{~nm}$ )

TABLE. 1

Independent Samples Test

\begin{tabular}{|c|c|c|c|c|c|c|c|c|c|c|}
\hline & \multicolumn{2}{|c|}{$\begin{array}{c}\text { Levene's Test for } \\
\text { Equality of Variances }\end{array}$} & \multicolumn{7}{|c|}{ t-test for Equality of Means } \\
\hline & & \multirow[b]{2}{*}{$\mathrm{F}$} & \multirow[b]{2}{*}{ Sig. } & \multirow[b]{2}{*}{$\mathrm{t}$} & \multirow[b]{2}{*}{ df } & \multirow[b]{2}{*}{ Sig. (2-tailed) } & \multirow{2}{*}{$\begin{array}{c}\text { Mean } \\
\text { Difference }\end{array}$} & \multirow{2}{*}{$\begin{array}{l}\text { Std. Error } \\
\text { Difference }\end{array}$} & \multicolumn{2}{|c|}{$\begin{array}{l}95 \% \text { Confidence } \\
\text { Interval of the } \\
\text { Difference }\end{array}$} \\
\hline & & & & & & & & & Lower & Upper \\
\hline Whole D & $\begin{array}{l}\text { Equal variances } \\
\text { assumed }\end{array}$ & 8.224 & .004 & 4.003 & 327 & .000 & 23.839601 & 5.955067 & 12.124525 & 35.554678 \\
\hline & $\begin{array}{l}\text { Equal variances } \\
\text { not assumed }\end{array}$ & & & 4.905 & 150.454 & .000 & 23.839601 & 4.860094 & 14.236752 & 33.442451 \\
\hline
\end{tabular}

Table. 1 Procedure compares means for two groups of cases. If the significance value for the Levene's test is high (typically greater than 0.05) use the results that assume equal variances for both groups. A low significance value for the $t$ test (typically less than 0.05) indicates that there is a significant difference between the two group means. If the confidence interval for the mean difference does not contain zero, this also indicates that the difference is significant. 